\title{
Iran - Infrastructure, historical and current developments in performative pedagogy
}

\author{
Amir Hossein Esmkhani
}

\section{Introduction}

Theatre and other forms of art have played an unarguable part in the formation of cultures and civilizations all around the world. There is some proof that performance began even before language was invented by man. In their rituals and traditions, our earliest ancestors used their body to convey messages and performed rituals on different occasions. The history of our culture and civilization is replete with various forms of art and performance narrating the stories of generations. From mothers' bedtime stories to religious ceremonies, for a wide range of purposes, art in general and performance-based art in particular gave shape and meaning to human's everyday life experiences. This article will present an overview of the history of performative arts in Iran, how it has come to contribute to foreign language teaching, and outline its limitations and future projections.

\subsection{A brief history of performative arts in Iran}

Performative arts have a rather long history in Iran. In one of the most authoritative books on Iranian Performance Tradition, William O'Beeman (2011) presents the rich "tapestry" of Iranian traditional performance which took root many centuries ago, before Iran came into contact with the West.

He believes that those who are not familiar with Iranian culture may be truly surprised to discover that Iran has any noteworthy performance traditions at all. In his book he claims, "Iranian performance traditions strike deep to the roots of Iranian culture, and reveal truths about Iran that are profound and fascinating" (O'Beeman 2011: 12).

These performance traditions include the epic drama, Taziyeh, and the comic improvisatory Ruhozi, which have continued until this day. They are of aesthetic complexity, subtle and, in an unprecedented and unique way, reflect Iranian culture and thought, enriching all Iranian cultural expression, including literature, art, architecture and film.

After the Iranian revolution in 1978, there was some concern that these traditions, which had been an invaluable part of Iranian life for many centuries, might vanish. However, even though traditional performance has seen some decline after the revolution, its major tenets have remained almost intact. 
These performance traditions remain an exceptionally powerful part of Iranian life. Even highly westernized individuals appreciate them and watch them regularly. They remain an essential part of Iranian cultural heritage, and a key element in Iranian identity. Moreover, their strength extends to the rest of the Persianate world in Iraq, Afghanistan, Central Asia and beyond. They also affect the Shi'a world in Arab speaking regions such as Lebanon, Saudi Arabia, the United Arab Emirates, Azerbaijan, India and Pakistan. (ibid. 16)

Beeman shows the close association between the symbolism and structure of these performance forms with Iranian core culture and argues in anthropological terms that this association remains one of the most important reasons these traditions should be studied and revered. He also maintains that Iranian performance constitutes an assemblage of profoundly important aesthetic expression worthy of the most elevated attention among the cultural expressions of the world.

In another comprehensive book, The History of Theatre in Iran (2005), Willem M. Floor asserts:
Although most people do not speak of theater and Iran in the same breath, dramatic expression has always been a fixture of Iranian culture. Some 2500 years ago, kings and commoners alike were regaled by comic theater in the form of dance and mime, accompanied by music. The dan- cers often wore masks, a vestige of an earlier era when such dances were enacted as religious rites (Floor 2005: 7).

He confirms most of O'Beeman's descriptions of Iranian performative arts and adds that puppetry has also a long history, dating back to about 1000 B.C. He sees dramatic art in Iranian people's everyday rituals and contends that after the Islamic revolution some of the religious rituals were further established such as Tazieh. On the other hand a very strong form of performative arts called Ruhozi gradually declined.

\subsection{The state of the art in art-based pedagogy in Iran}

With such a deeply rooted tradition in performative arts in Iran, which has utilised performance on both sad and happy occasions, its educative use has been confined to indirect approaches through life long practices outside educational places. People have been exposed to various forms of dramatic activities in traditional rituals and ceremonies such as Ashoora and Tasooa, which are religious commemorations of Imam Hossein's martyrdom in Karbala. But as stated earlier, performative art has been underutilized in the field of education.

Historically, theatre (Nemayesh/teatre $=$ with French-like pronunciation) has not been a subject in the school curriculum, however, the capital Tehran has had a fine arts school (Honarestan) for secondary school students for almost half a century. It is only in the last few years that other cities have followed and seen their fine arts schools open. The main reason for the lack of focus 
on performative arts in pedagogical contexts to my mind is the conservative atmosphere in education with its emphasis on traditional approaches. In addition, Iranian scholars have never tried or maybe have failed to apply and customise drama-based teaching in accordance with the local culture, hence the lack of this powerful tool in our educational system.

At the tertiary level however, the picture is not that disappointing. The university of Tehran as one of the leading universities in Iran has had a faculty of fine arts for over a century with theatre, cinema and other related courses.

In 1957, the Department of Fine Arts as the first artistic and cultural organization, issued the establishment license of Dramatic Arts Office and, in 1960, was renamed Faculty of Dramatic Arts. After the reopening of universities in 1983, this school continued its activities under the name of Faculty of Cinema and Theater.

Now the Faculty of Cinema and Theater offers these programs:

\begin{tabular}{|l|c|c|c|}
\hline \multirow{2}{*}{ Field of Study } & \multicolumn{3}{c|}{ Academic Level } \\
\cline { 2 - 4 } & BA & MA & $\mathrm{PhD}$ \\
\hline Cinema & $\sqrt{ }$ & $\sqrt{ }$ & - \\
\hline Acting & - & $\sqrt{ }$ & - \\
\hline Puppet Theater & $\sqrt{ }$ & - & - \\
\hline Scenery Design & $\sqrt{ }$ & - & - \\
\hline Acting - Directing & $\sqrt{ }$ & - & - \\
\hline Dramatic Literature & $\sqrt{ }$ & - \\
\hline Animation & - & $\sqrt{ }$ & - \\
\hline Theater Directing & - & $\sqrt{ }$ & - \\
\hline
\end{tabular}

The University of Art is one of the accredited universities in Iran. Some parts of this university were established in 1979. Then in 1991, five different institutes of arts combined together and the University of Art was founded as the largest university in Iran devoted to the arts.

In 1979, after reorganizing five formerly independent institutions - The Conservatory of Music (1918), The College of National Music (1949), The College of Decorative Arts (1960), The College of Dramatic Arts (1964), and Farabi University (1975) -, it was formed as the Art Academic Complex, and in 1991, it was named the University of Art.

The University of Art is a major centre for art education in Iran with an international reputation. This university has been a pioneer in teaching many of art majors in Iran and the Middle East. The University of Art has five faculties in Tehran and Karaj: the Faculty of Applied Arts, the Faculty of Visual Arts, the Faculty of Cinema \& Theater, the Faculty of Music, and the Faculty of Architecture and Urban Planning.

Currently there are 3950 full-time students, 135 full-time faculty members, 
and 330 part-time professors at this university; with 21 bachelor's degree majors, 29 master's degree majors, and $5 \mathrm{PhD}$ majors.

Besides Tehran, a few other major cities - Shiraz, Esfahan, Tabriz -have university courses on theatre and other relevant art subjects.

\section{Drama/theatre in second language teaching/ learning in Iran and its limitations}

Second language teaching has followed the major universal trends in Iran since the first language school in Iran which opened in the 1950s. With a heavy focus on grammar-translation skills for more than five decades, it is only in the $21^{\text {st }}$ century that language schools have gradually shifted to communicative approaches.

\subsection{The impact of politics}

After the Islamic revolution in 1978, Iran closed its doors to the West and the political relations were limited to diplomatic ceremonies with the major powers of the world. In this era of international seclusion, the communicative use of English has not been a central focus for Iranian language learners until the last decade or so. Students focused more on grammar, reading and translation skills as they were attempting a university entrance exam at the end of the secondary school, which determined their future. Recently, however, together with many other countries, Iranians started to realise the importance of the very much neglected listening/speaking skills for communication purposes. Highly influential elements are the introduction of the Internet, Mobile Devices, Satellite Receivers, PCs, Tablets, and Globalisation in general. A rather open-door policy of the Iranian government towards the world in the current regime has also been somewhat effective in this regard.

\subsection{Private vs. public sectors}

Although the trend has been inclining towards more communicative approaches, this shift has been slow and gradual, as assessments and national measurements are still leaning towards more conservative and traditional methods. And this has led to a distinction between public educational institutions and privately owned language schools; the former being still mostly traditional and the latter more open to new approaches in language teaching. So when discussing the use of drama in language teaching in Iran, my focus will be on privately owned and run language schools, as there is no incorporation of art forms into language learning in state-owned schools whatsoever.

Private language schools have sprung in number in the last two decades. With only a few language centres until about 2005, there is now about one language school for every 20,000 people in cities; in my hometown Zanjan in the north-western part of Iran, with a population of about 500,000 people, there 
are now about 25 major language schools and even more local minor ones. This number attests to people's raised awareness regarding genuine acquisition of language to be much more than just the knowledge of grammatical rules and the ability to translate. This distinction is also evident in teacher recruitment. Type 1 are the state-run school teachers who have mastered in traditional skills of Reading, Writing and Grammar; whereas the private schools usually recruit teachers who are more fluent and efficient speakers of English. In this highly competitive market, private language schools are introducing new initiatives to attract as many customers as they can. They are advertising their use of modern approaches, among which is the implementation of drama activities.

\subsection{Art in the curriculum}

Few language schools have incorporated some drama-based approaches in their curriculum in Tehran and few other major cities. No language school has so far been confident enough to introduce drama as their main focus. This situation is due to many factors such as lack of people's awareness about the advantages of a performative-based language pedagogy, lack of teaching staff, lack of proper space, parents' expectations which are mostly tuned to the old regime, as well as government's restrictions. People in general and parents and students in particular have not heard about what drama-based teaching can contribute to the learning of foreign languages. Moreover, there is a shortage of teachers who have been trained to use performative techniques in their classes. Limited space of private language schools which usually accommodate around 20 students in a 30 sqm classroom adds to the complexity of the situation. Last but probably the most important is the governments' supervision on privately owned businesses. They will not allow businesses to practice anything unless they approve of it and unless there are no contradictions with the moral and religious norms. Theatre as an art form cannot be so much limited to these rigid rules, hence the rarity of dramatic approaches in language schools. As a result the current state of the art in utilizing performative arts in language teaching in Iran is not so bright.

\subsection{The significance of people's awareness}

People's awareness about the advantages that dramatic performance can bring to a language class seems limited. Furthermore, teachers are not trained to use drama in language learning classes and there are no adequate resources and training centres for them should they wish to do so. Unlike few universities and colleges in developed countries with heightened awareness of the significance of the drama-based language teaching, I believe the picture in the most educational parts of the world is rather bleak. I had an ELICOS (English Language Intensive Course for Overseas Students) teaching position in one of the leading language centres of Australia for 4 years. To my disappointment, language teaching still mostly follows the same traditional approaches, the justification of which 
is meeting the needs of and satisfying the overseas students, who are mostly Asian. There are very few countries in which language teachers can obtain certificates for teaching language through drama and Iran is no exception; there are no formal or even informal institutions for training the teachers and issuing certificates in drama-based language teaching.

\subsection{Projection about the future of pedagogical art in Iran}

As I believe the future of language learning will be closely tied in with the performative arts, the prediction is that the next few decades will witness the introduction of theatre and other art forms in language learning. In Iran, as mentioned earlier, the private education sector will most probably embark on this project well ahead of the public sector. The private sector is more motivated to do so for many reasons such as:

- Thriving in the competitive market

- Seeking customer satisfaction

- Being innovative

- Being more open to new methods

- Being pioneer in introducing new ideas

The projection for the appreciation and use of theatre/drama in language learning/teaching in Iran is expected to start from privately owned language institutes first and then Azad university is likely to show interest in this field much prior to the state universities for the reasons discussed earlier. It is unclear at this point as when exactly there will be courses in this field, however, the usual pattern in Iran is that first a few avant-gardes initiate an idea and if it succeeds then the rest will follow. I think drama pedagogy will be the future of language teaching and soon language centres using drama will spring up everywhere in the world.

\subsection{The Iranzamin language school project}

As the founder, manager and DoS at Iranzamin language school in Zanjan, Iran since 2002, I am in the process of introducing drama in the curriculum. This will be a gradual process for the reasons mentioned earlier, but we will hopefully start a dramatic centre of language teaching/learning. Lessons and activities will centre around the use of performative arts in language learning.

The Iranzamin language school is a fully private language school established in 2002, delivering general English language course for kids to adults of all age ranges in all proficiency levels. In 2002, Iranzamin started introducing communicative approaches in Zanjan province for the first time and soon it became one of the biggest language schools in the area. In 2005, there was 
a record enrolment of 2500 in one semester; however, due to the increasing number of language schools, we have had the flat approximate number of 1000 enrolments in each term in the last 5 years.

Although we know the limitations and shortcomings in launching drama pedagogy, such as lack of English language teachers to deliver drama-based lessons, lack of appropriate space, lack of academic local research, and so on, we are determined to be the first institution based on drama pedagogy and raise people's awareness about its great potential in language learning.

\section{Academic research on drama pedagogy in Iran}

Academic research on the impact of performative arts on language learning has been limited to only few studies, all of which have been conducted within the last six years.

The first one which examines the positive impact of performance on the literary knowledge of students, is only partially related to the central theme of this paper.

[1] http://www.tesl-ej.org/wordpress/issues/volume13/ej52/ej52a4/

This paper proposes that English literature students' knowledge of drama could increase drastically if they perform throughout the course. The participants of this research were 60 intermediate students of English Drama and the research was conducted over a whole semester. The participants were divided into 2 groups, experimental and control. The experimental group devoted most of the course time to performing the plays, while the other cohort only read the plays in the traditional manner. The findings suggest that performing the plays can have significantly positive impact on the tertiary level students' knowledge of English Drama. The contention of this paper is that performance should be added to the traditional approaches to studying English Drama.

The other two research papers are non-empirical library papers which have focused on literature review in this area with only a rather weak application to the context of Iranian classes.

[2]file:///C:/Users/paniz/Downloads/Using_Drama_in_Teaching_English_ as_a_For.pdf

This paper is rather a literature review and recommends a conservative incorporation of drama techniques as supplementary material, which is more tailored to the semi-traditional condition of language teaching in Iran.

[3] http://indianresearchjournals.com/pdf/IJSSIR/2012/September/ 3.pdf

The focus of this study is teaching of drama and its contribution to language teaching/learning in Iran and how it can best be implemented. In this research, drama refers to any imaginary situation which can be encountered in the students' daily lives. According to this study, the use of drama has many benefits, including the creation of a stress-free atmosphere, increasing students' sense of responsibility and autonomy, generating new knowledge, improving 
the pronunciation of English vocabulary, reaching a deeper level of cultural understanding, and also equipping students with more confidence to express themselves in public. The study was conducted in two different schools in Ilam province in Iran. Both teachers and students realized through the active use of drama in the classroom that true language learning is based on real, personalized communication, in contrast to traditional classroom instruction where the soul of language learning is missing.

\section{Final Words}

This paper has presented an overview of the state of the art of drama-based language teaching in Iran. It can be concluded that despite a long history of theatre, the educational potential of theatre has not been tapped into much yet. Lack of training centres, drama-based courses, and trained teachers, as well as a rather traditional approach of the decision makers have all had a negative impact on theatre/drama techniques in education in general and in language teaching in particular. It is hoped that privately owned language schools will start the adoption of performative arts in language teaching in a more communicative era in Iran.

\section{Bibliography}

Beeman, William O. (2011): Iranian Performance Tradition. Santa Ana, CA: Mazda Publishers

Floor, Willem M. (2005): The History of Theatre in Iran. Washington, DC: Mage Publishers

Gorjian, Bahman; Moosavinia, Syyed Rahim \& Jabripour, Azadeh (2010): Dramatic Performance in Teaching Drama in EFL Contexts. In: TESL-EJ $13 / 4$.

http://www.tesl-ej.org/wordpress/issues/volume13/ej52/ej52a4/ [last accessed December 27, 2016)

Moghaddas, Bahram \& Ghafariniae, Reza (2012): Applying Drama Techniques in Teaching English in Iran. In: International Journal of Social Science \& Interdisciplinary Research 1/9, 24-32. http: //indianresearchjournals.com/pdf/IJSSIR/2012/September/3.pdf [last accessed December 27, 2016] 